UDC: 622(497.1)(09)"1918/1921"

Александар Хорват

Универзитет у Новом Саду

Филозофски факултет

Докторанд

aleksandarhorvat1987@yahoo.com
Оригиналан научни рад

примљено: 21. март 2013

прихваћено: 1. октобар 2013

\title{
ЗНАЧАЈ ПЕЧУЈСКИХ РУДНИКА УГЉА У ПОЛИТИЦИ КРАЉЕВИНЕ СХС 1918-1921
}

Сажетак: Интерпретација историјског значаја печујских рудника угља у политици Краљевине СХC 1918-1921. познат је научни проблем у југословенској и постјугословенским историографијама. Међутим, аутори се нису бавили свеобухватном анализом овог питања. Исто тако, неке од интерпретација и постављених теза су погрешне, како због недостатне контекстуализације, тако и због погрешног тумачења генезе овог проблема. Осим тога, што је и најважније, није уочена веза између економских интереса Краљевине СХС у печујским рудницима и политике коју је водила у Барањи од 1919. и зачуђујућом сарадњом са печујским социјалистима и комунистима, све до епизоде са проглашењем „Барањске републике“. Стога, наш циљ у истраживању ће бити прецизна контекстуализација, реинтерпретација неких од постављених теза и анализа веза између представника Краљевине СХС и политичких кругова у Печују. Настојање југословенске државе да одржи контролу над рудницима и њиховом експлоатацијом, упркос одлукама Конференције мира у Паризу 1919-1920. и притиску сила Антанте да повуче војне и цивилне власти из дела Барање који је Тријанонским мировним споразумом припао Мађарској, довели су до међународног скандала и губитка угледа Краљевине СХС, поготово међу барањским становништвом.

Кључне речи: Краљевина СХC, Конференција мира у Паризу, барањско питање, печујски рудници угља.

Основа нашег истраживања полази од тезе да је питање експлоатације печујског угља било у значајној мери главни покретач већине процеса у Барањи у време југословенско-мађарског разграничења, па је стога потребно утврдити правце утицаја и развој овог проблема. Значај ових рудника у политици Краљевине СХС од 1918. до 1921. године није на задовољавајући начин разматран у оквиру југословенске, и касније српске историографије. ${ }^{1}$

\footnotetext{
${ }^{1}$ Историчар Андреј Митровић је у својим познатим студијама о Конференцији мира у Паризу и разграничењу Краљевине СХС са суседним државама 1919-1920. врло опширно писао о политици, коју је назвао „печујском амбицијом“. Међутим, његова разматрања нису обухватила генезу те политике, па услед тога није у потпуности разјаснио тај проблем и многа питања су остала отворена (Andrej Mitrović,
} 
Печујски рудници угља се налазе у фокусу српске политике, касније политике Краљевине СХС, од новембра 1918. Тада су се Печуј и већи део Барањске жупаније нашли под контролом српских трупа. Српске и савезничке снаге су још септембра 1918. пробиле Солунски фронт, да би већ 1. новембра Београд био ослобођен. Вођене интересима својих држава и ратним циљевима формулисаним у току рата, трупе Краљевине Србије и Антанте су почетком новембра 1918. прешле граничне реке између Србије и Аустроугарске монархије, заузимајући територије Баната, Бачке и Барање. У исто време, одвијао се распад Хабзбуршке царевине и грађанска револуција у Будимпешти. Проглашена је независна република Мађарска, на челу са председником владе Михаљем Карољијем. Уследило је формирање мађарских народних већа у појединим местима, чији је циљ био очување територијалног интегритета Угарске. Централно народно веће у Барањи налазило се у Печују. Дана 13. новембра 1918. потписана је Београдска конвенција о примирју између Антанте и Мађарске. Према њеним одредбама, требало је да се мађарске трупе у Јужној Угарској повуку иза линије Марош-Тиса-Суботица-БајаПечуј-Барч. Конвенцијом је загарантовано да ће у јужноугарским областима цивилна власт остати у рукама мађарске администрације. ${ }^{2}$ Већ сутрадан српска војска је ушла у Печуј, ${ }^{3}$ не слутећи да ће управо проблем око експлоатације рудника

Jugoslavija na konferenciji mira: 1919-1920, Beograd 1969; Andrej Mitrović, Razgraničenje Jugoslavije sa Mađarskom i Rumunijom 1919-1920, Novi Sad 1975). Митровићеви пропусти биће посебно размотрени у реинтерпретацији настанка политике „печујске амбиције“ на Конференцији мира. Ново светло на печујску политику Краљевине СХС унели су мемоари Милана Глибоњског, објављени 2009. године. Глибоњски је као уредник печујског листа Барањски гласник и учесник догађаја изнео низ корисних података о теми. Он је посведочио о разговорима које је водио са Николом Пашићем и Јованом Цвијићем у Паризу 1920, везаним за судбину разграничење у Барањи и значај који су рудници у томе имали (Милан Глибоњски, Барања: (1918-1923): (сећања) (прир. Василије Ђ. Крестић и Петар Крестић), Београд 2009). Печујске руднике и њихов значај помињу и Вук Винавер, Данило Кецић, Вујица Ковачев и Љубинка Трговчевић у својим радовима (Vuk Vinaver, Jugoslavija i Mađarska 1918-1933, Beograd 1971; Вук Винавер, Публицистичка делатност Беле Линдера и југословенско-мађарски односи 1922-1935, 3борник за историју 4, Нови Сад 1971, 151-163; Danilo Kecić, Sindikalni pokret železničkih radnika u Vojvodini 19181921, Novi Sad 1969; Vujica Kovačev, Organizacija mađarskih komunista-emigranata iz Baranje u Jugoslaviji 1921-1922. godine, Prilozi za istoriju socijalizma 10, Beograd 1976, 325-362; Љубинка Трговчевић, Научници Србије и стварање југословенске државе: 1914-1920, Београд 1986), али без свеобухватне анализе целокупног проблема. Винавер је увиђао значај печујских рудника у политици Краљевине СХС, али није повезивао ово питање са конкретним активностима југословенске владе у Барањи, које су се систематично одвијале до 1921. и знатно утицале на карактер југословенско-мађарских односа. Кецић је у својој студији о синдикалним организацијама железничких радника у Војводини 1918-1921, углавном на основу архивске грађе, изнео низ корисних података о дешавањима у Печују 1919. и фебруарском штрајку рудара, али није у целини обрадио њихову политичку и синдикалну активност, која се још динамичније наставила у наредне две године. Ковачевљев текст се бави комунистима-емигрантима из Барање у Краљевини СХС од 1922, али је у уводу дао опширан осврт на политичке догађаје у Печују 1919-1921, и везе печујских социјалиста и комуниста са београдском владом. Међутим, није уочио кључан научни проблем, односно да је делатност печујских левичара била диктирана од стране владе Краљевине СХС и условљена међусобним интересима. Трговчевић се кратко осврнула на неке од елемената „печујске политике“ југословенске делегације на Конференцији мира у Паризу, али њене тезе углавном се ослањају на Митровићеве интерпретације.

${ }^{2}$ V. Vinaver, Jugoslavija i Mađarska, 17-21.

${ }^{3}$ Стеван Михалџић, Барања од најстаријих времена до данас, Нови Сад 1937, 405; Стеван Михалџић, 
угља из околине града обележити развој догађаја у Барањи у наредне три године.

Питање експлоатације печујских рудника угља историјски је део опште кризе изазване последицама Првог светског рата и превладавања привредног наслеђа и деконсолидације након распада Аустроугарске монархије и формирања наследних држава. Краљевина СХC је имала велике проблеме са хроничном несташицом угља. Рудници у Србији су били у катастрофалном стању, како због пустошења од стране немачке и аустроугарске окупацијске управе, тако и због тога што су окупаторске трупе приликом повлачења уништиле већи део рударских постројења. ${ }^{4}$ Несташица угља је већ 1919. прерасла у акутну кризу, што је озбиљно доводило у питање функционисање транспорта и саобраћаја у целој Краљевини CXC. ${ }^{5}$ У тим условима, територије Баната, Бачке и Барање су биле усмерене на намиривање потреба за угљем из печујских рудника. Витални интерес Краљевине СXC постао је везан за контролу над њима и за њихову експлоатацију.

Проблем експлоатације печујских рудника угља на два поља је одређивао и усмеравао политику југословенске државе према барањском питању. С једне стране, то је био фактор у спољној политици, односно у раду делегације Краљевине СХC на Конференцији мира у Паризу. Од августа-септембра 1919, то питање добија једно од централних места у настојањима делегата за територијалним и економским добицима. Осим тога, питање печујских рудника је у значајној мери утицало на заоштравање југословенско-мађарских односа. С друге стране, проблем печујског угља је усмеравао вођење унутрашње политике Краљевине СХC у Барањи. Југословенске војне и цивилне власти су морале водити посебно опрезну политику према локалном становништву и радништву мађарске националности, јер су евентуална обустава рада или друге компликације могле довести у питање функционисање саобраћаја у свим областима некадашње Јужне Угарске. Спољнополитички и унутрашњополитички аспекти су се често прожимали, па је отварање политике „печујске амбиције“ на Конференцији мира условљавало промене на терену, у самој области.

Временом ће економски интерес Краљевине СХC у печујским рудницима постати основни покретач догађаја и политичких заплета у Барањи. То се назире већ од почетка српске окупације, иако су одредбе Београдске конвенције спречавале било какве интервенције војних власти у привреди и јавној управи. Међутим, односи снага су промењени већ 25. новембра 1918. Тада је Велика народна скупштина у Новом Саду донела одлуку о присаједињењу Баната, Бачке и Барање Србији, односно Југославији. Формирани су привремени органи нових власти: Народна управа ${ }^{6}$ као извршно тело и Велики народни савет као законодавни орган.

\footnotetext{
Барања - ослобођена, Споменица ослобођења Војводине, Нови Сад 1929, 83.

${ }^{4}$ Мари-Жанин Чалић, Социјална историја Србије 1815-1941, Беград 2004, 204-205.

${ }^{5}$ Smiljana Đurović, Kriza uglja na teritoriji Kraljevine SHS 1919. godine, Acta historico-oeconomica Iugoslavie 1, Zagreb 1974, 67-82.

${ }^{6}$ Народна управа је формално деловала до марта 1919, када је њена администрација у целини уклопљена у рад појединих министарстава Краљевине СХC. За то време, овај извршни орган је донео значајне одлуке у области судства и школства, према којима је ,језик странака језик суђења“ и „наставни језик је матерњи језик ученика“ (љубомирка Јудин, О раду Народне управе за Банат, Бачку и Барању 1918-1919,
} 
Територија на којој се простирала власт Народне управе у Банату, Бачкој и Барањи била је обухваћена демаркационом линијом, која је званично утврђена Београдском конвенцијом. Та линија се протезала северно од Печуја, Суботице, Баје и Темишвара. Када је 1. децембра 1918. проглашено југословенско уједињење и стварање Краљевине СХC, територије под контролом Народне управе постале су део југословенске државе. ${ }^{7}$

Преузимање цивилне власти био је главни задатак Краљевине СХC у Банату, Бачкој и Барањи, што је подразумевало кршење одредби Београдске конвенције. Тај процес је био узрокован потребом да се променама на терену ојачају захтеви југословенске делегације на Конференцији мира у Паризу и тако трајно обезбеде ове територије, али и настојањем да се изврши привредна стабилизација, пошто је мађарска администрација то онемогућавала одбивши сарадњу са војним властима. Народна управа је већ од децембра 1918. почела са постепеним смењивањем мађарских чиновника који нису хтели положити заклетву новој власти. Док су у Бачкој и Банату у почетку смене пролазиле без већих потреса, у Барањи је овај процес био ограничен националним саставом, односно апсолутном мађарском већином у овој области, ${ }^{8}$ као и потребом за експлоатацијом печујског угља. То је упућивало југословенске војне власти у овој области, а посебно Печују, да воде опрезнију и толерантнију политику према мађарском становништву, чиновницима и радницима. Због тога је неко време покушавано успостављање сарадње са мађарским цивилним властима у граду.

Ипак, командант југословенских трупа у Печују, потпуковник Милош Цветић, није успео да успостави сарадњу војних и цивилних власти. Градска управа је остала у рукама мађарске администрације на челу са градоначелником Андором Нендвичем. Цветић је безуспешно покушао да оствари сарадњу са бискупом Ђулом Зичијим, како би обезбедио бар неку подршку за предстојеће економске мере. ${ }^{9}$ Већ 26. новембра 1918. српска команда донела је одлуку о ограниченом промету роба. На тај начин отежана је опскрба Будимпеште сировинама из Барање. ${ }^{10}$ Убрзо је отпочело и заплењивање угља из печујских рудника. Међутим, Мађарско народно веће је у Печују организовало митинг 3. децембра 1918, на којем је осуђена југословенска окупација и све одлуке Новосадске скупштине. ${ }^{11}$ Ипак, кријумчарење роба и животних намирница из Барање у суседне области је достигло забрињавајуће размере, што је отежавало економску стабилизацију Барањске жупаније. Српска команда је донела нову одредбу: да се намирнице и робе могу извозити само са

\footnotetext{
Зборник за друштвене науке 51, Нови Сад 1968, 5-35).

7 О Великој народној скупштини у Новом Саду и раду Народне управе вид. више у: Споменица ослобођења Војводине: 1918, Нови Сад 1929; Petar Pekić, Povijest oslobođenja Vojvodine, Subotica 1939; Dimitrije Boarov, Politička istorija Vojvodine; u trideset tri priloga, Novi Sad 2001; Драго Његован, Присаједињење Срема, Баната, Бачке и Барање Србији 1918: документи и прилози, Нови Сад 2001.

${ }^{8}$ Према подацима Ј. Босендорфера, у целој Барањи је 1910. живело скоро 200.000 Мађара и мало више од 40.000 Југословена. Он овај однос приписује интензивној мађаризацији у току XIX века (Јosip Bösendorfer, Nešto malo o našoj Baranji, Osijek 1940, 47).

${ }^{9} \mathrm{~V}$. Kovačev, Нав. дело, 327.

${ }^{10}$ Jug, 28. studenoga 1918, 226.

${ }^{11}$ J. Bösendorfer, Нав. дело, 36.
} 
њеном дозволом. ${ }^{12}$ Учестали протести Мађарског народног већа због ових одлука, као и заплењивање угља из печујских рудника у све већим количинама, отворили су пут присилној промени општинске управе. ${ }^{13}$

Пошто су југословенске власти установиле да је печујски угаљ изузетно високог квалитета и да је несметана експлоатација неопходна за функционисање сабраћаја у Банату, Бачкој и Барањи, одлучено је да се агресивнијим наступом Барањска жупанија стави под контролу Народне управе, односно владе у Београду. Мађарски чиновници су смењивани са положаја у жупанијској администрацији, а упражњена места су попуњавана југословенским кадровима. ${ }^{14}$ Међутим, мађарска влада није одустајала од области које је сматрала интегралним деловима своје државе. Осим тога, онемогућено јој је да користи привредне потенцијале окупираних области, што је било у супротности са Београдском конвенцијом. Исто тако, мађарско становништво у Банату, Бачкој и Барањи било је у целини изиритирано процесом смењивања старе администрације и осталим мерама Народне управе.

Велика прекретница у развоју догађаја је мађарски национални генерални штрајк 21. и 22. фебурара 1919, који је захватио Темишвар, Суботицу, Сомбор и Печуј. Организације мађарске социјалдемократске странке и бројни синдикални савези, инструисани од стране мађарске владе, припремили су заједнички план политичке акције. Радништво у Печују било је додатно незадовољно мерама југословенских војних власти, којима су спречавани јавни зборови синдиката, излажење радничких новина, а уз то животни стандард и наднице су били ниски. Штрајк у Печују је избио 22. фебруара. Захтевано је уклањање југословенске администрације и смена великог жупана Владислава Пандуровића, постављеног од стране Народне управе. У осталим местима Бачке и Баната штрајк је безуспешно окончан већ 23. фебруара, али у Печују је настављен све до 12. марта 1919. То је изазвало крупне последице, јер је обустављена експлоатација печујског угља, што је могло довести до застоја целокупног железничког и бродског саобраћаја у Банату, Бачкој и Барањи. Лист Népszava је писао да у штрајку учествује око 15.000 радника, против „империјалистичке незаситости српске окупаторске силе“. Могућност саобраћајног колапса присилила је југословенског премијера Стојана Протића и министра унутрашњих послова Светозара Прибићевића да отпочну преговоре са представником мађарске владе о враћању старе управе у Печују. Представници Краљевине СХC су морали да пристану на уступке. У споразуму је обећана обнова рада синдикалних организација и излажења радничке штампе у Печују, администрација у Барањи је поново требало да се нађе под контролом мађарских власти, а Пандуровић је повучен. Штрајк је прекинут и поново је почео обустављени рад. Споразум о повлачењу југословенске администрације потписан је 21. марта 1919. ${ }^{15}$ Реакција Срба и Шокаца у Барањи је била веома бурна. Организовани су

\footnotetext{
${ }^{12}$ Neven, 22. siječnja 1919, 15.

${ }^{13}$ V. Vinaver, Jugoslavija i Mađarska, 326-327.

${ }^{14}$ Neven, 22. veljače $1919,42$.

${ }^{15}$ V. Vinaver, Jugoslavija i Mađarska, 40-41; Šandor Mesaroš, Položaj Mađara u Vojvodini 1918-1929, Novi Sad 1981, 76-79; D. Кесіс́, Нав. дело, 36-51; V. Kovačev, Нав. дело, 328-239.
} 
митинзи на којима се протестовало против споразума. ${ }^{16}$ Успех генералног штрајка у Печују био је условљен значајем експлоатације печујских рудника угља, што је неопрезна политика југословенских власти довела у питање. Међутим, избијање комунистичке револуције у Мађарској истог дана када је потписан споразум у потпуности је поништило велики део донесених одлука и обећања. Градска управа у Печују је остала у рукама Нендвича, али је југословенска администрација задржала власт у жупанијској управи. Револуција је утицала на промену става конзервативних, антикомунистичких мађарских кругова у Печују, који ће од тада остварити сарадњу са југословенском администрацијом. ${ }^{17}$ Власти Краљевине СХС су увиделе да насилним мерама и брзим променама неће постићи много, па ће све до краја окупације 1921. водити политику темељену на сарадњи са мађарским политичким круговима: до слома комунистичке револуције у Мађарској августа 1919. са конзервативним круговима, присталицама Хортија, тзв. белим Мађарима, а после са социјалистима и комунистима.

Од краја августа и почетка септембра 1919. значај печујских рудника је добио сасвим нову димензију. Тада се појавила иницијатива у раду делегације Краљевине СXC на Конференцији мира у Паризу, дефинисана као политика „печујске амбиције“. До тада је однос југословенске владе и делегације према питању разграничења у Барањи пролазио кроз више фаза, са различитим варијантама потенцијалне државне границе: 1. Предлог шефа војне мисије Краљевине СХС у Паризу, генерала Петра Пешића, из јануара 1919, као први незванични захтев југословенске делегације, који је границу у Барањи постављао северно од Печуја; 2. Третирање Барање као територијалног захтева од којег се може одустати (фебруар-април 1919); 3. Настојање да се избори граница јужно од Мохача до августа 1919. Баш тог месеца је територијална комисија Конференције мира донела предлоге о границама између Краљевине СХС и Мађарске, који су, у ствари, представљали и дефинитивна решења. Овим предлозима, Краљевини СХC је припао мањи, јужни део Барање, површине $1.147 \mathrm{~km}^{2} .{ }^{18}$

Према истраживањима Андреја Митровића у раду „Разграничење Југославије са Мађарском и Румунијом 1919-1920“, до политике „печујске амбиције“ је дошло услед две иницијативе: антропогеографских истраживања Јована Цвијића у Барањи и подстрека Министарства саобраћаја. Према Митровићу,

\footnotetext{
${ }^{16}$ Baranjski glasnik, 14. novembra 1919, 3.

${ }^{17}$ Једна делегација мађарских аристократа из Барање путовала је у јулу 1919. на Конференцију мира у Париз, како би подржали продужење југословенске окупације. Том приликом су скренули пажњу да би печујске руднике захватио слом уколико би војска Краљевине СХC напустила Барању. Овај наступ мађарских аристократа био је мотивисан страхом од комунистичке револуције у Мађарској (А. Mitrović, Razgraničenje Jugoslavije sa Mađarskom i Rumunijom, 163-166).

${ }^{18} \mathrm{O}$ барањском питању на Конференцији мира, осим наведених Митровићевих радова, вид. више: Богдан Кризман, Питање гранииа Војводине на Паришкој мировној конференцији 1919. године, Зборник за друштвене науке, 24, Нови Сад 1959, 31-72; Bogdan Krizman, Bogumil Hrabak, Zapisnici sa sednica Delegacije Kraljevine SHS na Konferenciji mira u Parizu 1919-1920, Beograd 1960; Bogumil Hrabak, Ustanovljavanje jugoslovenske granice u Baranji 1919-1920. godine, Istorija XX veka 1-2, Beograd 1992, 5160; Davorin Taslidžić, Kocka je bačena, Beli Manastir 1988; Дневник проте Стевана Михалиића (прир. Драго Његован), Нови Сад - Београд, 2000.
} 
у почетку је била реч о два одвојена захтева. Цвијић је у септембру 1919. током боравка у Барањи дошао до нових етничких и географских сазнања, па је предложио делегацији измену дотадашње политике, а Министарство саобраћаја је хтело добити експлоатацију угља из печујских рудника. Митровић закључује да су се временом ове две иницијативе спојиле у политику печујске амбиције и захтевање границе северно до Печуја. ${ }^{19}$

Међутим, политика „печујске амбиције“ је сазревала неколико месеци уочи овог захтева Министарства саобраћаја, што је претходило и Цвијићевој активности. Тезе које Митровић износи у ствари су део те политике, узроковане сасвим другим факторима. Већ од јуна 1919. често се говорило о проблемима са несташицом угља у Банату, Бачкој и Барањи. Проблеме је узроковао одлазак великог броја рудара комуниста у Мађарску од марта 1919, због избијања комунистичке револуције. То је угрозило експлоатацију печујског угља, па су довођени рудари из Босне и Славоније, како би се колико-толико одржала производња. ${ }^{20}$ Посланик у Привременом народном представништву Краљевине СХС, Мита Клицин, у неколико наврата је на скупштинским заседањима излагао о проблемима везаним за успостављање сабраћаја у некадашњим јужноугарским областима и стању у печујским рудницима угља. ${ }^{21}$ Из Барање су у поједина министарства пристизале разне представке и резолуције становништва, у којима је истицан њихов економски значај. $^{22}$ Барањски школски надзорник, Милан Ђ. Ћосић, у једном извештају министру војном јула 1919, писао је о богатим рудницима, који су 1895 . деоничарском друштву донели добитак од 1.170 .809 круна. ${ }^{23}$

Иако је југословенска влада свакако увиђала значај печујских рудника, до коначног преокрета у политици Краљевине СХC и њене делегације у Паризу долази у августу 1919. Пошто је тада сломљена револуција у Мађарској, око 4.200 радника комуниста се појавило на демаркационој линији у Барањи тражећи да их југословенске власти приме под своју заштиту. Гарантовали су верност и оданост Краљевини СХC, као и подизање производње у рудницима угља. Командант барањске посаде, Војин Чолак Антић, дозволио им је прелазак, сви су разоружани и запослени у печујским рудницима. ${ }^{24}$ Производња је заиста повећана неколико пута. О томе сведоче извештаји штампе. Према писању новосадског Јединства, производња угља у рудницима је током августа 1919. износила 40 вагона, ${ }^{25}$ а већ почетком следећег месеца подигнута је на 120-130 вагона. ${ }^{26}$ Тек после овог развоја догађаја, Министарство саобраћаја је 4. септембра 1919. упутило телеграм

\footnotetext{
${ }^{19}$ A. Mitrović, Razgraničenje Jugoslavije sa Mađarskom i Rumunijom, 209-215.

${ }^{20} \mathrm{~V}$. Kovačev, Нав. дело, 330.

${ }^{21}$ Стенографске белешке Привременог народног представништва Краљевине Срба, Хрвата и Словенаца, од 41-53. састанка, III свеска, Београд 1920, 184; Стенографске белешке Привременог народног представништва Краљевине Срба, Хрвата и Словенаца, од 54-100. састанка, IV свеска, Београд 1920, 171.

${ }^{22}$ Представка Срба Барањаща престолонаследнику Александру, у: М. Глибоњски, Барања, 88-91.

${ }^{23}$ Школски надзорник Милан Ђ. Ћосић генералу Стевану Хаиићу, у: М. Глибоњски, Барања, 79-83.

${ }^{24}$ Јединство, 7. новембра 1919, 145.

${ }^{25}$ Јединство, 22. августа 1919, 97.

${ }^{26}$ Јединство, 7. септембра 1919, 107.
} 
делегацији у Париз, са питањем да ли је добијена експлоатација печујских рудника. Делегација је одговорила да експлоатација није ни тражена, али да је захтевано од Мађарске да лиферује Краљевини СХС по 100.000 тона угља за пет година. Ранислав Аврамовић, стручњак делегације за привредна питања, сматрао је да ће се веома тешко добити експлоатација самих рудника ${ }^{27}$.

У својим разматрањима, Митровић је изнео још једну погрешну тезу. Он је сматрао да је иницијатива Министарства постављена као економско питање, али да је врло брзо допуњена територијалним захтевима, јер је Краљевина СХC дошла на идеју да тражи Печуј на основу привредне аргументације. Ипак, унутар делегације вероватно је већ крајем августа 1919. формирана идеја о потреби проширења територијалних захтева у Барањи. У београдској Политици 3. септембра 1919. објављен је чланак, у којем је реч о припреми неког новог меморандума делегације Краљевине CXC о барањском питању. Према тексту тог меморандума, гранична линија је повучена иза планине Мечек, на основу: 1. етничког принципа, јер је становништво спорне зоне југословенско; 2. зато што тај крај чини економску целину; 3. због потребе привреде Краљевине СХC за печујским угљем; 4. из стратегијског разлога, по којем би повлачење границе иза Мечека било стална опасност за Бачку у случају рата. ${ }^{28}$

Пошто је Политика већ крајем августа имала информације о овом меморандуму који је захтевао границу северно од Печуја, сасвим је јасно да Цвијић није на своју руку отишао у Барању, него да је упућен од стране делегације да прикупи нове аргументе како би што прецизније била формулисана политика „печујске амбиције“. Цвијић је већ 12. септембра 1919. из Мохача послао резултате својих истраживања експертима и делегатима великих сила. Предлагао је да граница буде успостављена на Мечеку на основу географског начела и да је карактер целе Барање словенски. Међутим, за своје тврдње није изнео никакве доказе, него се уздао у престиж своје научне речи. ${ }^{29}$

Од јесени 1919. питање разграничења у Барањи је заузимало централно место у раду југословенске делегације. У почетку је највећа пажња усмерена на добијање привремене експлоатације печујских рудника, да би у октобру 1919. отпочео озбиљнији рад на образложењима територијалних захтева о граничној линији северно од Печуја. Нови југословенски премијер Љубомир Давидовић је 20. септембра 1919. упутио телеграм делегацији у којем је писао да би губитак печујских рудника изазвао слом железничког саобраћаја. Након премијерове иницијативе, проблем је поверен на проучавање групи економских стручњака: Драгутину Дучићу, Кости Куманудију и Раниславу Аврамовићу. Стручњаци су сматрали да су мали изгледи за добијање експлоатације печујских рудника, јер ће и Мађарска оскудевати у угљу, а и зато што се у рудницима у то време све више ангажовао енглески капитал. Осим тога, експерти су подвукли добар квалитет

\footnotetext{
${ }^{27}$ A. Mitrović, Razgraničenje Jugoslavije sa Mađarskom i Rumunijom, 215-216.

${ }^{28}$ Политика, 3. септембар 1919, 4161.

${ }^{29}$ A. Mitrović, Razgraničenje Jugoslavije sa Mađarskom i Rumunijom, 210-213; A. Mitrović, Jugoslavija na konferenciji mira, 144; V. Vinaver, Jugoslavija i Mađarska, 97; Љ. Трговчевић, Нав. дело, 296.
} 
печујског угља и његов значај за југословенску индустрију и саобраћај. Главни предлог је био да се извесне количине угља добију у виду репарација на пет година. Председник економске секције Коста Стојановић је у писму делегацији нагласио „да се настоји добити експлоатација у властитој режији, и да ће бити без вредности свако обећање угља ако се добију само писмене гаранције, а да све остане у мађарским и енглеским рукама“. Ускоро, 22. октобра 1919, југословенска делегација је први пут иступила са званичном нотом о граничној линији северно од Печуја. У сплету етничких и географских аргумената посебно је наглашен значај рудника угља за југословенску државу. ${ }^{30}$

У исто време, велике силе су хтеле затворити питање мађарских граница и одузети војничку предност Краљевини СXC, па су наредиле евакуацију југословенске војске из дела Барање који је према решењима територијалне комисије припао Мађарској. Премијер Давидовић је у телеграму делегацији у Паризу нагласио да би напуштање печујских рудника изазвало слом саобраћаја и додао да, ако се већ област мора напустити, бар не дође до евакуације рудника. У исто време, делегација у Паризу је развила тактику одржавања војничких позиција и покушала да поново отвори питање исправке границе. Делегати су од Давидовића затражили да Цвијић поново дође у Париз, како би лично известио експерте великих сила о путовању у Барању. Међутим, Цвијић је сматрао да су шансе за добијање северне Барање и печујских рудника минималне, с обзиром на то да је простор био изван раније званично поднетих захтева Краљевине СХC. ${ }^{31}$

Врховни савет Конференције мира је 7. новембра 1919. упутио ноту влади и делегацији Краљевине СХC, у којој је поново наређивао евакуацију српске војске из Барање. У ноти је наглашено да евакуација не предодређује решење Конференције у погледу југословенског захтева за експлоатацијом печујских рудника. Ипак, југословенска делегација је и током новембра настављала са писањем нових нота, тражећи експлоатацију печујских рудника и доказујући њихов значај за економску рестаурацију југословенске државе. Крајем новембра и почетком децембра 1919. премијер Давидовић и барањски велики жупан Владислав Пандуровић су послали телеграме делегацији, у којима је тражено да се никако не изврши евакуација северне Барање, јер би недостатак угља из печујских рудника изазвао велике саобраћајне тешкоће у целој Војводини, али и на међународној прузи ЉубљанаЗагреб-Београд. Пандуровић је писао и Цвијићу да помогне барањску ствар код владе. Међутим, активност делегације је опадала. Већ почетком децембра 1919. сматрала је да се поводом барањског питања ништа не може учинити. На другој страни, премијер је писао о могућности да се опет ангажује Цвијић, па чак и регент Александар. Међутим, делегати су у том периоду већу пажњу посветили питању разграничења у Албанији и репарацијама, иако је влада у Београду веровала да се може нешто постићи у погледу Печуја. Мобилисан је и регент Александар, и он

\footnotetext{
${ }^{30}$ A. Mitrović, Razgraničenje Jugoslavije sa Mađarskom i Rumunijom, 216-221; A. Mitrović, Jugoslavija na konferenciji mira, 144; V. Vinaver, Jugoslavija i Mađarska, 97.

${ }^{31}$ A. Mitrović, Razgraničenje Jugoslavije sa Mađarskom i Rumunijom, 221-222; Љ. Трговчевић, Нав. дело, 297.
} 
децембра 1919. долази у Париз. У једном интервјуу, изјавио је да Антанта позива Краљевину СХС да евакуише Барању, али се прво мора обезбедити печујски угаљ за југословенску државу. Истог месеца поднесена је нова нота делегације у којој се тражило да се мировним уговором са Мађарском, Краљевини СХС осигура бар 60 одсто продукције печујског угља. ${ }^{32}$

Међутим, крајем године постепено се одустајало од инсистирања на барањском питању. Томе је доприносио притисак око договарања границе са Италијом, где се нису назирала никаква решења. Као значајан резултат дипломатских борби, југословенске трупе су ипак остале на демаркационој линији у Барањи, иако су савезници изричито наређивали да се изврши евакуација. Почетком 1920. Цвијић је ипак поново допутовао у Париз, да би се ангажовао у решавању барањског питања. Припремио је нове ноте којима је доказивао како је Мечек најбоља граница, међутим, ове активности су остале без ефекта, јер велике силе нису намеравале да мењају одлуке територијалне комисије од августа $1919 .{ }^{33}$

У исто време, решено је питање експлоатације печујских рудника. Репарациона комисија за југословенска и румунска питања израдила је предлог 9. јануара 1920. Одређено је да део печујског угља припадне Краљевини СХС, у количини коју би накнадно одредио Организациони комитет Репарационе комисије. Предложено је и да Врховни савет захтева повлачење југословенске војске из Печуја, одмах пошто са Мађарском буде склопљен аранжман о месечним испорукама угља. Савет министара иностраних послова усвојио је предлог 10 . јануара $1920 .^{34}$

У фебруару 1920. из Барање је упућено једно изасланство у Париз. Чинили су га Милан Ђ. Ћосић, барањски жупанијски школски надзорник, и Милан Глибоњски, уредник печујског Барањског гласника. Глибоњски је у својим сећањима детаљно писао о боравку у Паризу. У то време се говорило о могућем плебисциту у Барањи, међутим, Пашић је ово решење одбацио на седници делегације 24. фебруара 1920. Он је тада изјавио да поново покретање барањског питања може нанети штету интересима Краљевине СХC, јер је „наша рђава администрација одстранила од нас Немце и Јевреје, то би ови, у случају плебисцита, гласали несумњиво за Мађаре, те би на тај начин могли да изгубимо много што шта друго“, па би „боље било сад не дирати у то питање ${ }^{\text {‘35 }}$.

У разговору који је обавио са Цвијићем и Пашићем пре повратка у Печуј, Глибоњски је сазнао још неке веома важне информације о расплету барањског питања. Према Цвијићевим речима, „Енглези су закупили од Мађарске печујске руднике угља на дужи низ година, па тако и железничку пругу Печуј-Вилањ-Мохач, којом ће се угаљ транспортовати до Дунава. Тиме је запечаћена била и судбина ова

\footnotetext{
${ }^{32}$ A. Mitrović, Razgraničenje Jugoslavije sa Mađarskom i Rumunijom 223-226; A. Mitrović, Jugoslavija na konferenciji mira, 97, 144; V. Vinaver, Jugoslavija i Mađarska, 97-98, 110.

${ }^{33}$ A. Mitrović, Razgraničenje Jugoslavije sa Mađarskom i Rumunijom, 235-241.

${ }^{34}$ Исто, 240.

35 В. Krizman, В. Hrabak, Нав. дело, 273-274. Корупцијске афере у Барањи и недолично понашање чиновника Краљевине СХС били су теме готово свих новина у држави и извештаја војних и просветних власти из саме покрајине.
} 
два места, која су, захваљујући свом положају ушла у интересну сферу Енглеске“. Глибоњски је разговарао и са Пашићем, који је рекао: „Од нашег професора сте чули како стојимо. Нисмо се могли хватати у коштац са нашим великим Савезником. Он ће нам још требати. Таква вам је политика“. ${ }^{36}$ Изјаве Пашића и Цвијића слагале су се са садржајем писма економских експерата политичкој делегацији од 4. октобра 1919, о ангажовању енглеског капитала у рудницима. И југословенско посланство у Лондону је током фебруара 1920. извештавало да енглески индустријалци настоје да приграбе акције великих предузећа у Мађарској. ${ }^{37}$ Југословенска штампа је у априлу 1920. писала о посети енглеског пуковника Гренфела, повезујући је са вестима о преузимању печујских рудника од стране једног великог енглеског новчаног удружења. Извештавано је о преговорима тог друштва и садашњих власника рудника „Дунавског паробродског друштва“ и преласку рудника у енглеске руке. ${ }^{38}$

Према томе, изузетно важну улогу у решавању барањског питања у овој фази имали су: инвестирање енглеског капитала у печујске руднике и опредељење делегације за опрезнију тактику, да не би ново отварање питања Барање и евентуални плебисцит угрозили неке друге територијалне добитке, пошто је Мађарска тражила плебисцит за све територије, па су неке друге области могле доћи у питање.

У последњим данима рада Конференције мира поједини југословенски делегати и неколицина изасланика из Барање су ипак покушали да измене дефинитивне одлуке територијалне комисије. Ова активност је на крају сведена на покушај да се затражи продужење југословенске административне управе у целој Барањи на бар 5 до 10 година. Наведени покушај је аргументован потребом организованог пресељења југословенског становништва у део Барање који је припао Краљевини СХС и гаранцијом за извршење свих одредби мировног уговора од стране Мађарске. ${ }^{39}$ И ови покушаји су остали без резултата.

Дипломатске напоре југословенске делегације пратила је појачана политичка активност југословенских власти у самој области. Пошто су централна места у раду делегације била добијање експлоатације печујског угља, промена граничне линије која би ишла северно од Печуја, евентуално продужење окупације на 5-10 година и одгађање евакуације југословенских власти, у том правцу је усмеравана и политичка делатност. Промене у Мађарској условљавале су избор савезника. После стабилизације Хортијевог режима у Мађарској од новембра 1919, изгубљена је подршка мађарских чиновничких и конзервативних кругова у Печују и Барањи, док су се интереси Краљевине СХC сада поклапали са мађарским комунистичким и социјалистичким групама у граду. Иако су комунисти у југословенској држави 1920-1921. били изложени снажном притиску и репресији, то није сметало властима да са њима сарађују у Печују, како би били остварени политички и економски интереси.

\footnotetext{
${ }^{36}$ М. Глибоњски, Барања, 42-44.

${ }^{37}$ V. Vinaver, Jugoslavija i Mađarska, 119-129.

${ }^{38}$ Baranjski glasnik, 11. aprila 1920, 19; Јединство, 22. априла 1920, 274.

${ }^{39}$ М. Глибоњски, Нав. дело, 105-109.
} 
Већ у августу 1919. дошло је до споразума између југословенских власти и представника радништва. Велики раднички збор у Печ-Бањателепу одржан је 17. августа 1919. и на њему су рудари донели резолуцију у којој захтевају присаједињење целе Барање Краљевини СХС. Сутрадан, 18. августа, склопљен је споразум између социјалистичке странке и југословенских власти. Изасланици социјалиста су предали В. Чолак-Антићу и В. Пандуровићу меморандум на мађарском и француском језику, у којем се моли дозвола за поновно отварање радничког дома и избор водства странке, издавање страначког листа и допуштање радницима који долазе назад у Барању из подручја ван демаркационе линије да се могу без икаквих последица вратитити у своја места, као и да нико неће бити прогањан због учешћа у мађарској револуцији. Заузврат су обећавали дневну експлоатацију у рудницма од 140 вагона угља. ${ }^{40}$ Представници власти Краљевине СХC прихватили су понуду, а према сећањима Милана Глибоњског, целокупна сарадња са комунистима и социјалистима прихваћена је после наређења Министарства унутрашњих послова. ${ }^{41}$

Комунисти и социјалисти или „мађарске избеглице“, како су их званичним језиком називали у Печују, брзо су се организовали у политичко тело. Покренули су новине $М у н к а c^{42}$, а затим и читав низ листова са основним задатком да врше кампању за припајање целе Барање Краљевини СXC, између осталих: Pésci Újság и Baranya Magyar Újság. ${ }^{43}$ Заједно са радницима и рударима, у Барању су долазили и бројни угледни мађарски комунисти, социјалисти и либерални политичари као емигранти, додатно ојачавајући радничку организацију у Печују. ${ }^{44}$ Најпознатији међу њима били су Бела Линдер, министар одбране у Карољијевој влади, Оскар Јаси, министар за народности у истом кабинету, Ото Хофман, Мартин Ловаси, Ђула Хајду и други.

Када је потписан Тријанонски мировни споразум на Конференцији мира у Паризу 4. јуна 1920. и одређене границе Мађарске са њеним суседима, југословенске власти су постепено одустајале од захтева за изменом предвиђене граничне линије. Основни политички проблем постаје питање евакуације цивилних и војних власти Краљевине СХC са територија које су по мировном споразуму припале Мађарској. Из овога је произлазило и питање селидбе југословенског становништва. Међутим, политичка активност југословенских власти била је мотивисана настојањем да се настави експлоатација печујског угља, па је проблем селидбе у потпуности занемарен. Према Тријанонском споразуму, до евакуације страних трупа са окупираних територија требало је доћи по ратификацији документа у парламентима земаља потписница. Како смо већ споменули, силе Антанте су још од октобра и новембра 1919. инсистирале на евакуацији, желећи да се што пре изврши нормализација и стабилизација Подунавља, али и због економских интереса енглеског капитала у печујским рудницима. Притисак Антанте је југословенска

\footnotetext{
40 Јединство, 19. августа 1919, 95.

${ }^{41}$ М. Глибоњски, Нав. дело, 18.

${ }^{42}$ Исто, 18-19.

${ }^{43}$ J. Bösendorfer, Нав. дело, 38.

${ }^{44}$ V. Kovačev, Нав. дело, 330.
} 
влада енергично одбијала, јер би то онемогућило даљу експлоатацију угља у југословенској режији. То су уочавали амерички официри, чланови једне Антантине војне мисије, пишући да у Печују „функционише југословенска администрација и да је дневна производња угља 1.500 тона, од чега се 1.200 шаље на југ и да зато југословенска војска не мисли да напусти Барању“45. Појавила се и вест да „неки неодговорни елементи“ прете да потопе печујске руднике уколико војска Краљевине СХС напусти Барању ${ }^{46}$. Упорност владе Краљевине СХC и већ споменута активност југословенске делегације, спојене са појавом „неодговорних претњи“, резултирали су задржавањем позиција у делу Барање који је припао Мађарској.

Пошто је постало извесно да ће Тријанонски споразум бити ратификован до средине 1921, развијена је нова политичка концепција одржавања контроле над рудницима, формирањем једне аутономне области или републике у Барањи под југословенским протекторатом. Југословенске власти су се у току 1920. и 1921. потпуно посветиле реализацији овог плана, занемарујући организацију селидбе становништва. Успостављена је врло жива активност и комуникација између представника југословенске владе и пројугословенских социјалистичких и комунистичких група у граду. Појавиле су се и различите варијанте предлога о будућем статусу Барање.

Влада Краљевине СХС и печујски социјалисти и комунисти су своје позиције у граду ојачали одржавањем градских избора. Идеја о изборима је настала у Министарству унутрашњих послова, које је упутило поверљиво наређење југословенским властима у Барањи о потреби преузимања градске управе у Печују. Власти Краљевине СХC су закључивале да би то „био израз народне воље (плебисцит) који би се у случају потребе могао провести и у жупанији, односно неким деловима жупаније“. Уследили су преговори са водством печујских социјалдемократа. Они су се сложили око преузимања градске управе, али не простим именовањем нових чиновника, него градским изборима, после којих би биле извршене смене. Таква процедура би пружила законитост пред мађарском владом, Антантином мисијом у Печују и великим силама. Антантина мисија у граду је подржала одржавање избора. Социјалдемократи су пристали на сарадњу, јер је и њима одговарало да се југословенска окупација продужи. У поверљивој преписци барањског жупана исказано је задовољство што су они ,толико отуђени од мађарске државне идеје да су у оволикој мери подржали интересе Краљевине СХC““47. Иако су присталице Хортија, који су до тада водили градску управу, тражили што скорију евакуацију, а затим и бојкотовали изборе, избори су одржани 29. и 30. августа, тајним гласањем. ${ }^{48}$ Социјалдемократи су однели победу, а за градоначелника је изабран Бела Линдер, бивши министар у Карољијевој влади. Печујски избори утицали су на мађарско-југословенске односе. Мађарска јавност је оштро реаговала

\footnotetext{
${ }^{45}$ Политика, 4. децембра 1919, 4253.

${ }^{46}$ В. Hrabak, Нав. дело, 57.

${ }^{47}$ Архив Војводине, ф. 83, к. 1, пов. бр. 68/920.

${ }^{48}$ Baranjski glasnik, 3. avgusta 1920, 35; 8. avgusta 1920, 36; 15. avgusta 1920, 37; 22. avgusta 1920, $38 ; 29$. avgusta 1920,$39 ; 5$. septembra 1920, 40.
} 
назвавши изборе пучем ${ }^{49}$ и „издајом према мађарској домовини“, а Печуј „градом греха“" у којем се шири бољшевичка делатност. ${ }^{50}$

Избори су били део ширег плана о стварању неке врсте аутономије за део Барање који је припао Мађарској. Према печујском моделу градских избора, предвиђани су избори у целој Барањи, па би затим становништво донело одлуку о статусу Барање. Међу печујским социјалдемократима појављују се различите варијанте за решење проблема. Иако су разне политичке групе, антихортијевске, анексионистичке, либералне и комунистичке биле зближене ставом да треба одложити евакуацију, оне нису имале хомоген став о начину одлагања одласка југословенских власти.

Преовладавајући став у печујским политичким круговима о потреби продужења евакуације, док не буде оборен Хортијев режим у Мађарској и не успостави се демократски режим, изнели су Оскар Јаси и Бела Линдер тадашњем премијеру Миленку Веснићу, током боравка у Београду новембра 1920. То је био предлог аутономног статуса за део Барање који је припао Мађарској, под протекторатом Краљевине СXC. ${ }^{51}$ На једном збору у Печују у децембру 1920. истакнута је иста теза о потпуној аутономији Барање под југословенским протекторатом. ${ }^{52}$ Југословенска штампа је почела писати о „слободној републици“ у Барањи, коју ће прогласити Линдер и Јаси, ${ }^{53}$ а новине у Мађарској су забринуто одговарале да београдска влада крши установе Тријанонског уговора на штету Мађарске, па чак и да је проблем „Барањске републике“ усмерен против савезника. ${ }^{54}$

Дискусије о „Барањској републици“ су постајале све динамичније како се ближила предвиђена ратификација Тријанонског споразума. Најактивнији је био печујски градоначелник Линдер. У току 1921. водио је разговоре са чешким послаником од којег је тражио зајам за куповину оружја, ${ }^{55}$ а од посланика Француске, Енглеске, Италије и Румуније у Београду продужење југословенске окупације на 5 година. Међутим, нико није показао превише разумевања за ове идеје ${ }^{56}$ осим владе Краљевине СХС и југословенске јавности. У југословенској штампи је истакнута теза о потреби „спасавања Барање“ и одржавању општинских избора, као подлози за некакав плебисцит у будућности. ${ }^{57}$ Тадашњи премијер Никола Пашић је 12. јула 1921. посланицима великих сила објашњавао да су захтеви за евакуацијом неразумни. ${ }^{58}$

Ипак, Тријанонски споразум је ратификован у јулу 1921, а евакуација предвиђена за август 1921. Међутим, долази до још једног покушаја да се измене

\footnotetext{
${ }^{49}$ V. Vinaver, Jugoslavija i Mađarska, 168.

${ }^{50}$ Baranjski glasnik, 12. septembra 1920, 41; 19. septembra 1920, 42; 9. oktobra 1920, 45.

${ }^{51}$ Baranjski glasnik, 27. novembra 1920, 52.

${ }^{52}$ Baranjski glasnik, 17. decembra 1920, 55.

53 Јединство, 15. децембра 1920, 465.

${ }^{54}$ Neven, 29. prosinca 1920, 286.

${ }^{55}$ Baranjski glasnik, 19. aprila 1921, 71.

${ }^{56}$ V. Vinaver, Jugoslavija i Mađarska, 167-168; Јединство, 18. маја 1921, 585.

${ }^{57}$ Јединство, 1. jula 1921, 619.

${ }^{58}$ V. Vinaver, Jugoslavija i Mađarska, 168-169.
} 
одлуке Конференције мира, као резултат сарадње југословенске владе и печујских пројугословенских група. Проглашена је „Барањска република“ 14. августа 1921, под протекторатом Краљевине СХС и Мале Антанте. Међутим, након снажног притиска великих сила, југословенска влада је ипак пристала да евакуише трупе, до чега је дошло 20. и 21. августа $1921 .^{59}$ Са повлачењем трупа престала је да постоји и „Барањска република“. Пошто селидба становништва није припремљена, како је писала осјечка Стража цела „будалаштина“60 са проглашењем републике се претворила у бежање и скандал.

На тај начин је неславно завршена југословенска окупација северне и средње Барање, али за интересе Краљевине СХC врло корисна епизода са експлоатацијом печујског угља. Сасвим је сигурно да је питање печујских рудника угља обликовало југословенску политику у Барањи. Та политика није била доследна. У општим линијама није пратила снажну антикомунистичку оријентацију југословенске државе. То није могло донети углед у земљама Антанте, које су своју политику темељиле на стриктном спречавању било каквих комунистичких активности и потенцијалних револуција. Тежња да се по сваку цену обезбеди печујски угаљ водила је политику Краљевине СХC у авантуризам. Непоштовање потписаних уговора и сарадња са комунистима и социјалистима нису били чврст темељ за грађење печујске политике. Питање експлоатације печујских рудника је засигурно у великој мери одредило судбину барањског питања на Конференцији мира. Међутим, било би погрешно овам фактору дати превелику важност, како чини Глибоњски, јер, како смо видели, на решавање питања разграничења у Барањи су утицали и други, значајнији елементи. Недоследност политике и авантуризам су резултирали губитком угледа југословенских власти, посебно међу барањским становништвом, али и заоштравањем односа са Мађарском.

Хроничан недостатак угља у обе државе свакако је био полазна тачка у формулисању њихових политика и стратегија везаних за Барању, а поготово територије око Печуја и Мохача. Печујски рудници угља и питање њихове експлоатације до 1921. су у значајној мери придонели немогућности озбиљније стабилизиције, не само у односима између ове две државе него и у целом Подунављу. Повлачењем југословенских трупа из Барање један од значајних камена спотицања је уклоњен, а југословенско-мађарски односи су у наредним годинама почели да се побољшавају.

Извори и литература:

Извори:

Архив Војводине, фонд Барањске жупаније, Нови Сад, бр. 83.

Глибоњски, Милан, Барања: (1918-1923): (сећања) (прир. Василије Ђ. Крестић и Петар Крестић), Београд 2009.

\footnotetext{
${ }^{59}$ Политика, 16. августа 1921, 4781.

${ }^{60}$ Стража, 17. августа 1921, 101.
} 
Дневник проте Стевана Михалиића (прир. Драго Његован), Нови Сад - Београд, 2000.

Zapisnici sa sednica delegacije Kraljevine SHS na Mirovnoj konferenciji u Parizu 1919-1920, prir.

Bogdan Krizman i Bogumil Hrabak, Beograd 1960.

Михалџић, Стеван, Барања - ослобођена, Споменица ослобођења Војводине, Нови Сад 1929.

Присаједињење Срема, Баната, Бачке и Барање Србији 1918: документи и прилози (прир.

Драго Његован), Нови Сад 2001.

Споменииа ослобођења Војводине: 1918, Нови Сад 1929.

Стенографске белешке Привременог народног представништва Краљевине Срба, Хрвата и Словенаиа, од 41-53. састанка, III свеска, Београд 1920.

Стенографске белешке Привременог народног представништва Краљевине Срба, Хрвата и Словенаца, од 54-100. састанка, IV свеска, Београд 1920.

Периодика: Baranjski glasnik, Jединство, Jug, Neven, Политика, Стража.

Литература:

Boarov, Dimitrije, Politička istorija Vojvodine: u trideset tri priloga, Novi Sad 2001.

Bösendorfer, Josip, Nešto malo o našoj Baranji, Osijek 1940.

Vinaver, Vuk, Jugoslavija i Mađarska 1918-1933, Beograd 1971.

Винавер, Вук, Публицистичка делатност Беле Линдера и југословенско-мађарски односи 1922-1935, Зборник за историју 4, Нови Сад 1971, 151-163.

Đurović, Smiljana, Kriza uglja na teritoriji Kraljevine SHS 1919. godine, Acta historicooeconomica Iugoslavie 1, Zagreb 1974, 67-82.

Јудин, Љубомирка, О раду Народне управе за Банат, Бачку у Барању 1918-1919, Зборник за друштвене науке 51, Нови Сад 1968, 5-35.

Kecić, Danilo, Sindikalni pokret železničkih radnika u Vojvodini 1918-1921, Novi Sad 1969.

Kovačev, Vujica, Organizacija mađarskih komunista-emigranata iz Baranje u Jugoslaviji 1921-1922. godine, Prilozi za istoriju socijalizma 10, Beograd 1976, 325-362.

Кризман, Богдан, Питаюе граница Војводине на Паришкој мировној конференцији 1919. године, Зборник за друштвене науке 24, Нови Сад 1959, 31-72.

Mesaroš, Šandor, Položaj Mađara u Vojvodini 1918-1929, Novi Sad 1981.

Mitrović, Andrej, Jugoslavija na Konferenciji mira: 1919-1920, Beograd 1969.

Mitrović, Andrej, Razgraničenje Jugoslavije sa Mađarskom i Rumunijom 1919-1920, Novi Sad 1975.

Михалџић, Стеван, Барања од настаријих времена до данас, Нови Сад 1937.

Pekić, Petar, Povijest oslobođenja Vojvodine, Subotica 1939.

Taslidžić, Davorin, Kocka je bačena, Beli Manastir 1988.

Трговчевић, Љубинка, Научници Србије и стварање Југославије 1914-1920, Београд 1986.

Hrabak, Bogumil, Ustanovljavanje jugoslovenske granice u Baranji 1919-1920. godine, Istorija XX veka 1-2, Beograd 1992, 51-60.

Чалић, Мари-Жанин, Социјална историја Србије 1815-1941, Београд 2004. 


\title{
SIGNIFICANCE OF THE COAL MINES OF PÉCS IN THE POLITICS OF THE KINGDOM OF SERBS, CROATS AND SLOVENES FROM 1918 TO 1921
}

\begin{abstract}
Summary
An interpretation of the historical significance of the coal mines of Pécs in the politics of the Kingdom of Serbs, Croats and Slovenes from 1918 to 1921. The topic is addressed in Yugoslav and post-Yugoslav historiography. However, no comprehensive analysis of the question has been published to date. Furthermore, some of the interpretations and hypotheses presented are incorrect, either because of inadequate contextualisation or because of flawed interpretations of the problem's origins. Most importantly, previous research has overlooked the connection between the economic interests of the Kingdom in the mines and the policies which it implemented in Baranja from 1919 onwards, besides its unlikely cooperation with the Socialists and Communists of Pécs, until the episode in which the so-called Baranja Republic was proclaimed. Accordingly, the aims of the present research are to delineate precisely the context of the question, to reinterpret some of the existing hypotheses, and to analyse the connections between representatives of the Kingdom of Serbs, Croats and Slovenes and political circles in Pécs. Attempts by the Yugoslav state to maintain control of the mines and their operations - despite the decisions of the Paris Peace Conference of (1919-1920) and pressure by the Allied powers for military and civilian authorities to be withdrawn from those parts of Baranja which had been assigned to Hungary under the terms of Trianon provoked an international scandal and corresponding loss of face for the Kingdom, particularly among the populace of Baranja.
\end{abstract}

Keywords: Kingdom of Serbs, Croats and Slovenes, Paris Peace Conference, Baranja question, coal mines of Pécs. 